\title{
BUDIDAYA UDANG WINDU, Penaeus monodon PADA PADAT PENEBARAN BERBEDA DI TAMBAK TANAH GAMBUT
}

\author{
Akhmad Mustafa ${ }^{*}$ ), Adi Hanafi ${ }^{*}$, dan Brata Pantjara $\left.{ }^{*}\right)$
}

\begin{abstract}
ABSTRAK
Tanah gambut telah banyak dijadikan tambak, namun padat penebaran yang optimal untuk budidaya udang windu di tambak tanah gambut belum diketahui. Penelitian bertujuan mengetahui pertumbuhan, kelangsungan hidup, produksi, dan rasio konversi pakan serta kualitas tanah dan air pada berbagai padat penebaran udang windu di tambak tanah gambut. Penelitian dilaksanakan di tambak tanah gambut Delta Tampina, Kecamatan Malili, Kabupaten Luwu menggunakan enam petakan yang masing-masing berukuran $500 \mathrm{~m}^{2}$ yang terlebih dahulu direklamasi selama dua bulan. Perlakuan yang dicobakan adalah berbagai padat penebaran udang windu yaitu: 2,4 , dan 8 $\mathrm{ekor} / \mathrm{m}^{2}$, masing-masing dengan dua ulangan yang disusun berdasarkan rancangan acak lengkap. Udang windu dipanen setelah dipelihara selama 105 hari. Tambak tanah gambut masih tergolong agak masam, masih berada pada tahap reaksi reduksi, kandungan bahan organik dan Fe serta rasio C-N sangat tinggi, sedangkan kualitas air secara umum layak untuk budidaya udang windu. Padat penebaran yang dicobakan pada tambak tanah gambut berpengaruh tidak nyata $(P>0,05)$ terhadap berat individu dan kelangsungan hidup, tetapi berpengaruh nyata $(P<0,05)$ terhadap produksi udang windu dan rasio konversi pakan. Berat individu tertinggi $(27,73 \mathrm{~g})$ diperoleh pada padat penebaran $4 \mathrm{ekor} / \mathrm{m}^{2}$, kelangsungan hidup tertinggi $(65,30 \%)$ diperoleh pada padat penebaran terendah $\left(2 \mathrm{ekor} / \mathrm{m}^{2}\right)$, dan produksi tertinggi $\left(52,78 \mathrm{~kg} / 500 \mathrm{~m}^{2}\right)$ diperoleh pada padat penebaran tertinggi $\left(8 \mathrm{ekor} / \mathrm{m}^{2}\right)$, sedangkan rasio konversi pakan terendah $(1,60)$ diperoleh pada padat penebaran terendah $\left(2 \mathrm{ekor} / \mathrm{m}^{2}\right)$. Dengan demikian, padat penebaran udang windu di tambak tanah gambut masih dapat ditingkatkan di atas $8 \mathrm{ekor} / \mathrm{m}^{2}$ sampai padat penebaran di mana peningkatan produksi sudah menurun.
\end{abstract}

\section{ABSTRACT: The Performances of Tiger Prawn, Penceus monodon, Stocked at Different Densities in Peat Soil Pond, by: Akbmad Mustafa, Adi Hanafi, and Brata Pantjara}

The experiment was conducted based on the fact that peat soil pond could be used for tiger prawn culture, but the information on optimum stocking density is not available. Therefore, it was important to determine the effect of stocking densities on growth, survival rate, production, and feed conversion ratio (FCR) of tiger prawn cultured in such a pond. Soil and water quality were also observed. The experiment was conducted in peat soil ponds in Tampina Delta, Malili Subdistrict, Luwu Regency. Six ponds of $500 \mathrm{~m}^{2}$ each was used in this experiment after soil reclamation had been done for two months. The stocking densities applied were: 2 , 4, and 8 ind. $/ \mathrm{m}^{2}$, with two replicates each, which were arranged for a completely randomized design and cultured for 105 days period. The peat soil ponds contained high organic matter and $\mathrm{Fe}$ as well as high C-N ratio. The soil chemical reaction still in reduction stage. Water quality observed was suitable for culturing tiger prawn. The stocking density had no significant $(P>0.05)$ effect on individual weight and survival rate, but showed significant $(P>0.05)$ effect on the production and FCR. The highest individual weight $(27.73 \mathrm{~g})$ was obtained at stocking density of $4 \mathrm{ind} . / \mathrm{m}^{2}$, the highest survival rate $(65.30 \%)$ at the stocking density of 2 ind. $/ \mathrm{m}^{2}$, while the highest production $\left(52.78 \mathrm{~kg} / 500 \mathrm{~m}^{2}\right)$ at the stocking density of 8 ind./ $\mathrm{m}^{2}$. The lowest FCR $(1.60)$ was obtained the stocking density of 2 ind. $/ \mathrm{m}^{2}$. Seem to be that higher stocking density than $8 \mathrm{ind} . / \mathrm{m}^{2}$ is possible to be applied until the production increase begins to decrease.

KEYWORDS: Prawns, peat soils, fish ponds

*) Peneliti pada Balai Penelitian Perikanan Pantai, Maros 


\section{PENDAHULUAN}

Tanah gambut merupakan satu di antara jenis tanah bermasalah yang luasnya sekitar 10,9 juta ha di Indonesia. Tanah gambut sering dijumpai di daerah pasang surut yang lingkungan perairannya mendukung usaha budidaya tambak, menyebabkan tanah gambut banyak mendapat perhatian untuk dijadikan tambak. Namun demikian, kualitas tanah gambut yang belum diperbaiki umumnya kurang mendukung usaha tambak, karena $\mathrm{pH}$ yang rendah, kandungan bahan organik yang tinggi, dan kandungan senyawa toksik yang juga cukup tinggi. Sehingga Poernomo (1988) melaporkan bahwa tambak tanah gambut pada awalnya tidak langsung bisa berproduksi atau rendah produktivitasnya dan tidak stabil. Mustafa et al. (1992) mendapatkan pertumbuhan yang lambat (19 g/ekor) dan kelangsungan hidup yang rendah (30\%) dari udang windu, Penaeus monodon pada padat penebaran 4 ekor $/ \mathrm{m}^{2}$ selama empat bulan di tambak tanah gambut bukaan baru.

Daya dukung suatu lahan terutama lahan dengan kondisi yang baru (misalnya setelah diperbaiki melalui reklamasi) perlu diketahui agar produksi yang optimal dapat diperoleh dan kelangsungan usaha dapat berlanjut. Dengan demikian, padat penebaran perlu dikaji pada budidaya udang windu di tambak tanah gambut, karena padat penebaran yang tepat dapat menentukan produksi yang optimal (Liao, 1977; Huet, 1978; Wallace et al., 1988; Bose et al., 1991). Padat penebaran optimal dapat bervariasi antara tambak karena respons pertumbuhan pada padat penebaran berbeda dapat tergantung pada ukuran dan produktivitas tambak (Huet, 1978), kuantitas makanan alami yang tersedia (Maguire dan Leedow, 1983), kondisi fisika-kimia air, sistem produksi yang diterapkan (Trzebiatowski et al., 1981 dalam Papoutsoglou et al., 1987), sistem yang diterapkan dalam penumbuhan makanan alami, kedalaman air, pengelolaan air (Apud, 1988) dan kualitas pakan (Zonneveld dan Fadholi, 1991). Penelitian bertujuan untuk mengetahui pertumbuhan, kelangsungan hidup, produksi dan rasio konversi pakan serta kualitas tanah dan air dalam budidaya udang windu pada padat penebaran berbeda di tambak tanah

gambut. Dari penelitian ini diharapkan dapat memberikan informasi padat penebaran udang windu yang optimal pada tambak tanah gambut yang tergolong baru dan telah direklamasi.

\section{BAHAN DAN METODE}

Percobaan dilaksanakan di tambak tanah gambut Delta Tampina, Kecamatan Malili, Kabupaten Luwu, Sulawesi Selatan dari bulan Februari sampai Mei 1993.

Tambak yang digunakan berukuran $500 \mathrm{~m}^{2}$ sebanyak enam petak. Sebelum persiapan tambak, dilakukan perbaikan kualitas tanah melalui reklamasi selama dua bulan seperti dilaporkan secara rinci oleh Mustafa et al. (1994). Persiapan tambak meliputi pengeringan pelataran, perataan pelataran, pemasangan saring- 
an di pintu air dan pipa goyang, pemberantasan hama dengan menggunakan saponin dosis $40 \mathrm{ppm}$, pengapuran dengan dosis $3 \mathrm{t} / \mathrm{ha}$, dan pemupukan urea dengan dosis $100 \mathrm{~kg} / \mathrm{ha}$ dan TSP dengan dosis $50 \mathrm{~kg} / \mathrm{ha}$. Benur windu ukuran pascalarva-18 dari panti pembenih terlebih dahulu didederkan dalam hapa di tambak tanah gambut lainnya selama tujuh hari pada kepadatan 3 ekor/L sebelum ditebar di tambak percobaan.

Perlakuan padat penebaran yang dicobakan adalah: 2 ekor $/ \mathrm{m}^{2}$ (1.000 ekor/ petak), 4 ekor $/ \mathrm{m}^{2}$ (2.000 ekor/petak), dan $8 \mathrm{ekor} / \mathrm{m}^{2}$ (4.000 ekor/petak), masing-masing dengan dua ulangan yang disusun berdasarkan rancangan acak lengkap.

Pengapuran pada kaki pematang bagian dalam dilakukan setiap akan turun hujan dengan dosis $1 \mathrm{~kg} / 10 \mathrm{~m}$ pematang yang ditebar merata $(8 \mathrm{kali}$ pengapuran selama penelitian). Pergantian air sebanyak $5-20 \%$ dari volume total dilakukan setiap hari secara gravitasi. Pengukuran kualitas air berupa $\mathrm{pH}$ (dengan $\mathrm{pH}$ solution) dilakukan dua kali dalam sehari (pagi dan sore) serta suhu (dengan termometer), salinitas (dengan refraktometer), kecerahan (dengan piring secchi), dan kedalaman air (dengan tongkat penduga) dilakukan setiap hari. Di samping itu juga diadakan pengukuran oksigen terlarut dan suhu (dengan DO-meter) pada setiap 4 jam selama 24 jam pada setiap bulan. Pengambilan contoh air untuk dianalisis di laboratorium dilakukan setiap 15 hari meliputi $\mathrm{NH}_{4}-\mathrm{N}, \mathrm{NO}_{3}-\mathrm{N}, \mathrm{NO}_{2}-\mathrm{N}, \mathrm{PO}_{4}-\mathrm{P}$, dan bahan organik terlarut (DOM). Pengambilan contoh tanah secara komposit untuk setiap petakan dilakukan sebelum penebaran dan setelah panen. Peubah kualitas tanah yang dianalisis berupa $\mathrm{pH}$, redoks (reduksi-oksidasi), bahan organik, $\mathrm{N}, \mathrm{P}, \mathrm{Fe}, \mathrm{Al}$, dan tekstur.

Pengukuran berat udang windu dilakukan setiap 15 hari yang merupakan dasar. penentuan dosis pakan. Pakan komersial (rata-rata kandungan protein $38 \%$ dan lemak $3 \%$ ) diberikan dengan dosis $100 \%$ dari berat total pada awal pemeliharaan yang selanjutnya menurun menjadi $2 \%$ dari berat total saat menjelang panen. Panen dilakukan setelah udang windu dipelihara selama 105 hari yang dilanjutkan dengan pengukuran berat individu dan produksi serta penghitungan kelangsungan hidup (Ricker, 1975) dan rasio konversi pakan (Trino et al., 1992).

Data berat individu, kelangsungan hidup, dan produksi udang windu serta rasio konversi pakan yang diperoleh dianalisis ragam mengikuti rancangan acak lengkap menggunakan perangkat lunak program MSUSTAT. Peubah yang berbeda nyata diuji lanjut dengan uji Beda Nyata Terkecil (BNT) pada selang kepercayaan 95\% (Petersen, 1985). Data kualitas tanah dan air dianalisis secara deskriptif. 


\section{HASIL DAN PEMBAHASAN}

\section{Kualitas Tanah}

Sebelum penebaran udang windu, kualitas tanah di antara petakan tambak dari setiap perlakuan relatif sama (Tabel 1). Angka keasaman $(\mathrm{pH})$ tanah masih tergolong agak masam, tanah masih melakukan reaksi reduksi, kandungan bahan organik sangat tinggi, $\mathrm{N}$ tergolong rendah, dan rasio $\mathrm{C}-\mathrm{N}$ tergolong sangat tinggi, sedangkan kandungan Al tidak terdeteksi dengan tekstur lempung berdebu. Setelah panen, terjadi perubahan kualitas tanah (kecuali kandungan $\mathrm{Al}$ dan tekstur), namun relatif sama di antara ketiga perlakuan. Dalam hal ini, padat penebaran udang windu yang dicobakan belum mempengaruhi kualitas tanah tambak tanah gambut. Terlihat bahwa terjadi penurunan $\mathrm{pH}$, redoks, bahan organik, rasio $\mathrm{C}-\mathrm{N}, \mathrm{P}$, dan $\mathrm{Fe}$ tanah, tetapi sebaliknya terjadi peningkatan $\mathrm{N}$ tanah.

Tabel 1. Nilai rata-rata peubah kualitas tanah pada tambak tanah gambut sebelum penebaran dan sesudah panen udang windu yang dibudidayakan dengan padat penebaran berbeda

Table 1. Average value of soil quality of peat soil pond before stocking and after harvesting of tiger prawn cultured at different stocking densities

\begin{tabular}{|c|c|c|c|c|c|c|c|c|c|c|}
\hline \multirow{2}{*}{$\begin{array}{l}\text { Thltu pengamatan } \\
\text { Observacion rive }\end{array}$} & \multirow{2}{*}{$\begin{array}{l}\text { Il } \\
\text { lepadatan } \\
\text { srocking } \\
\text { densily } \\
\text { (ind } / \text { m2) }\end{array}$} & \multicolumn{2}{|c|}{ pW/Redox (V) } & \multirow{2}{*}{$\begin{array}{l}\text { Bahan } \\
\text { organil } \\
\text { Organic } \\
\text { matuer } \\
(\%)\end{array}$} & \multirow{2}{*}{$\begin{array}{r}N \\
\quad \\
(x)\end{array}$} & \multirow{2}{*}{$\begin{array}{l}\text { CN } \\
\text { Rasio } \\
\text { Ratio }\end{array}$} & \multirow{2}{*}{$\begin{array}{c}P \\
\text { (ppm) }\end{array}$} & \multirow{2}{*}{$\begin{array}{r}\mathrm{Fe} \\
\text { (ppm) }\end{array}$} & \multirow{2}{*}{$\begin{array}{c}\mathbf{A} \\
\text { (ppm) }\end{array}$} & \multirow{2}{*}{$\begin{array}{l}\text { Tdstur } \\
\text { (Testure) }\end{array}$} \\
\hline & & 120 & $\mathbf{r C l}$ & & & & & & & \\
\hline Sebelum penebaran & 2 & $6,12 / 0,18$ & $6,24 / 0,15$ & 25,02 & 0,17 & 86,51 & 0,58 & 161,96 & nd & Silty loam \\
\hline \multirow[t]{2}{*}{ (Before stocking) } & 4 & $6,33 / 0,07$ & $6,49 / 0,02$ & 21,61 & 0,14 & 88,48 & 1,02 & 110,38 & nd & \\
\hline & 8 & $6,02 / 0,24$ & $5,98 / 0,26$ & 23,81 & 0,16 & 87,08 & 0,68 & 146,57 & nd & \\
\hline Setelah panen & 2 & $5,60 / 0,12$ & $5,71 / 0,10$ & 20,22 & 0,36 & 32,21 & nd & 63,12 & nd & Silty loam \\
\hline \multirow[t]{2}{*}{ (After barvesting) } & 4 & $6,00 / 0,09$ & $6,16 / 0,08$ & 13,86 & 0,24 & 33,37 & nd & 35,96 & nd & \\
\hline & 8 & $5,79 / 0,10$ & $5,90 / 0,09$ & 18,84 & 0,26 & 41,05 & nd & 40,32 & nd & \\
\hline
\end{tabular}

nd $=$ not detected

Potensi kemasaman tanah gambut yang masih tinggi merupakan penyebab menurunnya $\mathrm{pH}$ tanah sehingga kapur pertanian yang diberikan hanya dapat mempertahankan $\mathrm{pH}$ tanah sementara saja. Di samping itu, pengaruh kapur pertanian umumnya akan menurun mengikuti waktu. Telah dilaporkan sebelumnya, $\mathrm{pH}$ tertinggi pada tanah gambut sebagai akibat pemberian kapur pertanian dijumpai pada hari ke-15 setelah aplikasi dan selanjutnya terjadi penurunan (Mustafa et al., 1993).

Bahan organik tanah lebih rendah sesudah panen dibandingkan dengan sebelum penebaran. Hal ini dapat diakibatkan oleh pengaruh pengapuran yang dapat menurunkan kandungan bahan organik tanah seperti temuan Mustafa et al. (1992) sebelumnya pada tanah gambut. Hal ini menunjukkan bahwa selama percobaan terjadi peruraian bahan organik. 
Hasil peruraian bahan organik tanah dapat menghasilkan unsur-unsur sederhana termasuk $\mathrm{N}$, menyebabkan tingginya kandungan $\mathrm{N}$ tanah sesudah panen. Penyebab lainnya adalah sebagai akibat pemberian pupuk urea pada saat persiapan tambak. Rendahnya kandungan C-organik dan lebih tingginya $\mathrm{N}$ tanah sesudah panen menyebabkan rasio $\mathrm{C}-\mathrm{N}$ tanah menjadi lebih rendah, namun masih tetap tergolong sangat tinggi.

Setelah panen terjadi penurunan kandungan $\mathrm{Fe}$ dan $\mathrm{P}$ tanah jika dibanding sebelum penebaran. Penurunan kandungan Fe tanah itu dapat disebabkan oleh tercucinya Fe saat pembuangan air tambak dan atau dinetralisir oleh kapur. Sedangkan terjadinya penurunan kandungan $P$ juga disebabkan oleh pencucian. Telah dilaporkan oleh Widjaja-Adhi et al. (1988 dalam Widjaja-Adhi, 1994) bahwa, amonium, unsur basa, dan $\mathrm{P}$ mudah tercuci pada tanah gambut.

Secara umum terlihat bahwa dalam budidaya udang windu di tambak tanah gambut akan memberikan dampak positif maupun negatif terhadap kualitas tanah. Dampak positifnya berupa penurunan rasio C-N tanah yang berarti mempercepat peruraian bahan organik sehingga tanah menjadi lebih "matang" dan menurunkan penyebab kemasaman. Sebaliknya dapat berdampak negatif karena unsur yang diperlukan untuk pertumbuhan makanan alami seperti $P$ menjadi kurang dalam tanah.

\section{Kualitas Air}

Selama pemeliharaan, terlihat bahwa padat penebaran udang windu yang berbeda pada tambak tanah gambut belum memberikan pengaruh yang nyata pada kualitas air yang langsung diukur di lapang $(\mathrm{pH}$, salinitas, kecerahan, kedalaman). Dari Tabel 2 dan Gambar 1 terlihat bahwa $\mathrm{pH}$, salinitas, kecerahan, dan oksigen terlarut masih relatif sama di antara ketiga perlakuan dan masih berada pada batas yang layak untuk budidaya udang windu.

Nilai $\mathrm{pH}$ dan suhu air yang diperoleh dalam penelitian ini (Tabel 2) termasuk dalam batas layak, namun tidak optimal untuk budidaya udang windu. Menurut Poernomo (1988) batas pH dan salinitas air tambak masingmasing berkisar 7,0-8,7 dan 10-30 ppt, sedangkan batas yang optimal masingmasing berkisar 8,0-8,5 dan 15-25 ppt.

Kecerahan air tambak dapat dipengaruhi oleh plankton dan suspensi partikel koloid tanah, di samping itu pada tambak tanah gambut juga dapat disebabkan oleh humus dan suspensi hidroksida besi. Menurut Poernomo (1988) bahwa udang yang insangnya ditempeli partikel lumpur atau besi hidroksida bukan saja insangnya rusak, tetapi pernapasannya terganggu dan mudah kena infeksi "protozoa epibiont" dan bakteri. Nilai kecerahan yang diperoleh dalam penelitian ini masih berada pada batas yang layak untuk usaha budidaya tambak. Menurut Poernomo (1988) bahwa batas kecerahan air yang layak untuk budidaya udang windu adalah $25-60 \mathrm{~cm}$, sedangkan yang optimal adalah $30-40 \mathrm{~cm}$. 
Tabel 2. Nilai peubah kualitas air (rata-rata $\pm S D$ ) yang diukur dalam tambak tanah gambut selama pemeliharaan udang windu pada padat penebaran berbeda

Table 2. Water quality values (average $\pm S D$ ) measured in peat soil ponds used for tiger prawn culture at different stocking densities

\begin{tabular}{|c|c|c|c|c|}
\hline \multicolumn{2}{|l|}{$\begin{array}{l}\text { Variabel } \\
\text { Variable }\end{array}$} & \multicolumn{3}{|c|}{$\begin{array}{l}\left.\text { Padat penebaran (ind. } / \mathrm{m}^{2}\right) \\
\text { Stocking density }\left(\mathrm{ind} . / \mathrm{m}^{2}\right)\end{array}$} \\
\hline & & 2 & 4 & 8 \\
\hline \multicolumn{5}{|l|}{$\mathrm{pH}$} \\
\hline pagi (morning) & & $7,01 \pm 0,2638$ & $7,12 \pm 0,2998$ & $7,18 \pm 0,2928$ \\
\hline sore (afternoon) & & $7,39 \pm 0,2798$ & $7,40 \pm 0,2932$ & $7,51 \pm 0,3381$ \\
\hline Salinitas (salinity) & ppt & $12,23 \pm 1,9872$ & $12,77 \pm 1,9724$ & $12,82 \pm 1,2382$ \\
\hline Kecerahan (transparan & y) $\mathrm{cm}$ & $39,52 \pm 8,2025$ & $40,50 \pm 8,0740$ & $41,25 \pm 5,3033$ \\
\hline Kedalaman (depth) & $\mathrm{cm}$ & $63,05 \pm 4,4736$ & $63,08 \pm 3,3618$ & $62,92 \pm 4,2870$ \\
\hline NO2-N & ppm & $0,0236 \pm 0,0170$ & $0,0207 \pm 0,0114$ & $0,0181 \pm 0,0105$ \\
\hline NO3-N & ppm & $0,1419 \pm 0,0926$ & $0,111 \pm 0,0703$ & $0,1469 \pm 0,1111$ \\
\hline NH4-N & ppm & $0,0487 \pm 0,0266$ & $0,0342 \pm 0,0366$ & $0,0459 \pm 0,0349$ \\
\hline PO4-P & ppm & $0,0065 \pm 0,0034$ & $0,0044 \pm 0,0014$ & $0,0052 \pm 0,0038$ \\
\hline DOM & $\mathrm{ppm}$ & $5,08 \pm 1,2317$ & $5,60 \pm 0,7685$ & $4,88 \pm 0,8579$ \\
\hline
\end{tabular}

$D O M=$ dissolved organic matter

Oksigen terlarut merupakan peubah kualitas air paling penting bagi kehidupan organisme akuatik (Ahmad, 1991). Pada Gambar 1 terlihat bahwa kandungan oksigen terlarut cukup berfluktuasi mengikuti waktu. Batas oksigen terlarut yang layak untuk budidaya udang windu adalah 3-10 ppm dengan optimalnya 4-7 ppm. Oksigen terlarut lebih kecil $3 \mathrm{ppm}$ terjadi pada pengukuran pukul 05.00 WIT dan 09.00 WIT, namun tidak dijumpai adanya udang windu yang berenang di permukaan air tambak. Beberapa ahli (ASEAN, 1978) berpendapat bahwa kebutuhan minimal oksigen terlarut dari udang windu adalah 2 ppm. 
Dissolved oxygen (ppm)

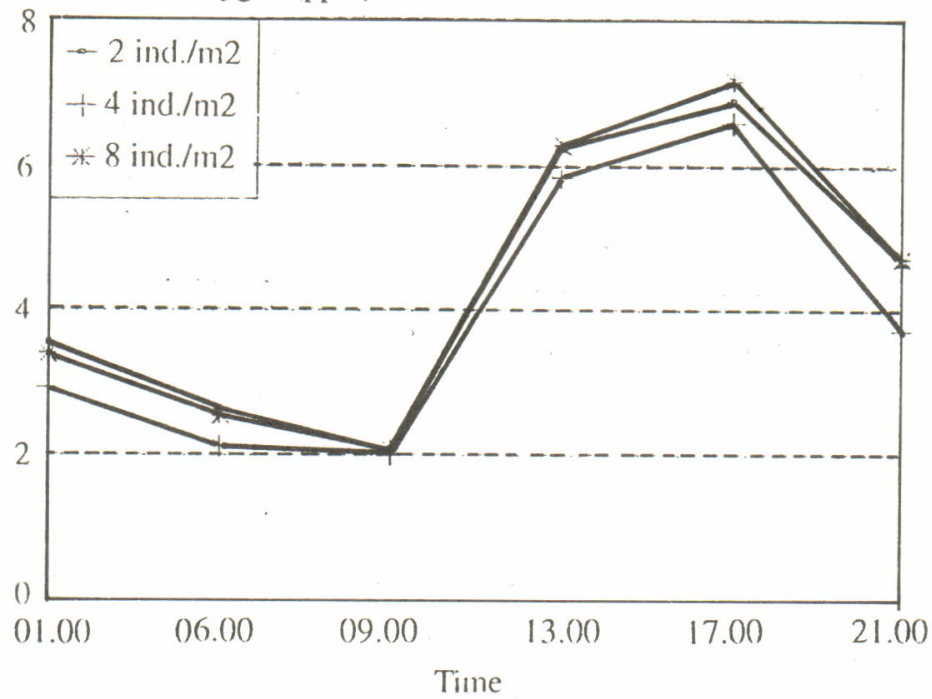

Gambar 1. Fluktuasi oksigen terlarut dalam budidaya udang windu pada padat penebaran berbeda di tambak tanah gambut

Figure 1. Dissolved oxygen fluctuation in peat soil ponds stocked with different densities of tiger prawn

Seperti halnya dengan oksigen terlarut, maka suhu air juga berfluktuasi mengikuti waktu (Gambar 2). Suhu air tertinggi pada ketiga perlakuan terjadi pada pukul 13.00, sedangkan suhu air terendah terjadi pada pukul 05.00 . Suhu air selama penelitian pada ketiga perlakuan tergolong tinggi, dapat mencapai $36^{\circ} \mathrm{C}$. Tingginya suhu air dapat diakibatkan oleh warna air yang lebih banyak berwarna coklat sebagai akibat koloid organik yang dapat menyerap panas yang lebih banyak, di samping volume air yang relatif kecil. Telah dilaporkan pula bahwa tanah gambut sangat cepat panas dan sangat lambat melepas panas, mengakibatkan suhunya sangat bervariasi pada permukaan tanah (Suhardjo, 1994) yang dapat mempengaruhi suhu air. Menurut Poernomo (1988) bahwa suhu air yang layak untuk budidaya udang windu berkisar $26-32^{\circ} \mathrm{C}$ dan optimalnya $29-30^{\circ} \mathrm{C}$. Sedangkan menurut Blanco (1972) dan Chen (1972) suhu air yang baik untuk budidaya udang windu adalah $25-30^{\circ} \mathrm{C}$.

Kualitas air yang diukur di laboratorium masih relatif sama dari ketiga perlakuan (Tabel 2). Dalam hal ini, perlakuan padat penebaran yang dicobakan belum mempengaruhi kualitas air yang diukur di laboratorium seperti $\mathrm{NO}_{2}-\mathrm{N}$, $\mathrm{NO}_{3}-\mathrm{N}, \mathrm{NH}_{4}-\mathrm{N}, \mathrm{PO}_{4}-\mathrm{P}$, dan bahan organik terlarut.

Nitrit $\left(\mathrm{NO}_{2}-\mathrm{N}\right)$ merupakan senyawa beracun terhadap udang, namun yang diperoleh dalam penelitian ini masih tergolong layak untuk budidaya udang windu. Seperti dikemukakan oleh Poernomo (1988), kisaran kandungan nitrit yang layak untuk budidaya udang windu adalah $0-0,25 \mathrm{ppm}$. 


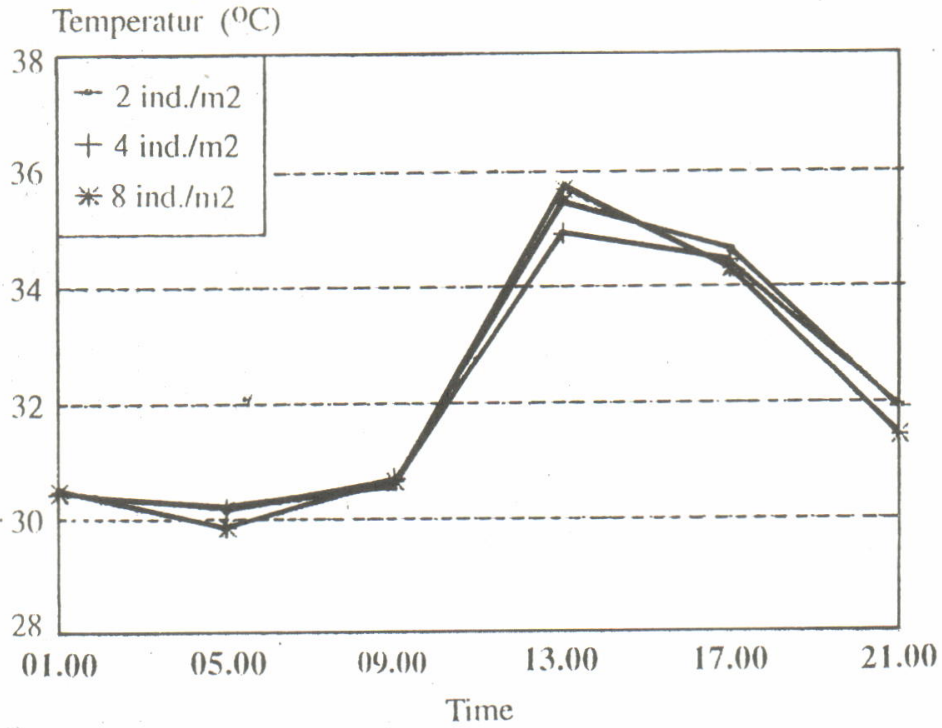

Gambar 2. Fluktuasi suhu air dalam budidaya udang windu pada padat penebaran berbeda di tambak tanah gambut

Figure 2. Water temperature fluctuation in peat soil ponds stocked with different densities of tiger prawn

Secara umum, sifat kimia air tambak tanah gambut dapat mendukung usaha budidaya udang windu, walaupun telah dilaporkan sebelumnya bahwa kualitas tanahnya masih tergolong kurang baik untuk budidaya udang windu. Dalam percobaan ini, pengelolaan air yang tepat merupakan faktor penyebab baiknya kualitas air. Seperti telah banyak dilaporkan oleh para peneliti bahwa faktor pengelolaan air merupakan kunci keberhasilan pengelolaan lahan rawa termasuk tanah gambut.

\section{Produksi dan Rasio Konversi Pakan}

Pertumbuhan udang windu selama penelitian yang dicirikan oleh berat individu dapat dilihat pada Gambar 3. Dari Gambar 3 terlihat bahwa berat individu terendah $(22,52 \mathrm{~g})$ dijumpai pada padat penebaran tertinggi (8 ekor $\left./ \mathrm{m}^{2}\right)$. Hal ini disebabkan oleh terjadinya persaingan terhadap ruang. Hal yang sama juga telah dilaporkan oleh beberapa peneliti bahwa semakin tinggi padat penebaran maka semakin rendah berat individu. Korelasi negatif sangat nyata yaitu $r=-0,721(P<0,01)$ telah diperoleh Mangampa dan Mustafa (1992) pada padat penebaran 5-20 ekor $/ \mathrm{m}^{2}$ dan $r=-0,980(P<0,01)$ oleh Wyban et al. (1987) pada padat penebaran udang windu $2,5-20$ ekor $/ \mathrm{m}^{2}$. 


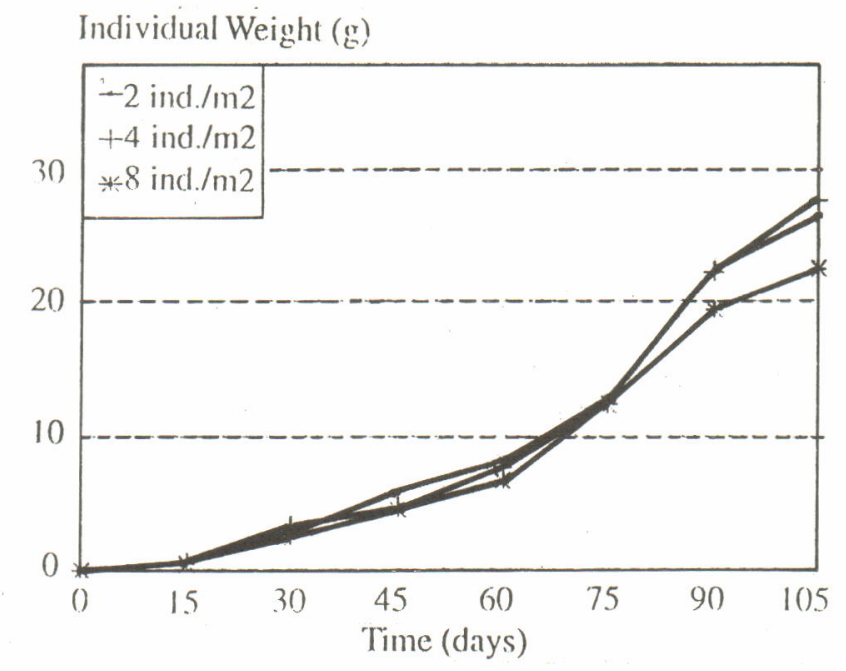

Gambar 3. Pertumbuhan udang windu pada padat penebaran berbeda di tambak tanah gambut selama 105 hari

Figure 3. Growth of tiger prawn raised for 105 days at different stocking densities in peat soil ponds

Pertumbuhan yang diperoleh pada ketiga perlakuan relatif lebih baik jika dibandingkan dengan pertumbuhan udang windu yang dipelihara di tambak yang tergolong normal. Menurut Akiyama dan Chwang (1989), udang windu yang dipelihara selama 105 hari pada padat penebaran 5 ekor $/ \mathrm{m}^{2}$ dan diberi pakan buatan dapat mencapai berat individu $22 \mathrm{~g}$. Pada padat penebaran 5, 10, dan $20 \mathrm{ekor} / \mathrm{m}^{2}$, Apud et al. (1980) mendapatkan berat individu berturut-turut 18,22; 11,22; dan 7,24 g pada budidaya udang windu sistem air mengalir dan diberi pakan selama 105 hari dengan menggunakan benur berukuran 0,45 g.

Analisis sidik ragam menunjukkan bahwa padat penebaran yang dicobakan berbeda tidak nyata $(P>0,05)$ terhadap berat individu dan kelangsungan hidup udang windu, tetapi berpengaruh nyata terhadap produksi udang windu dan rasio konversi pakan. Uji BNT menunjukkan bahwa padat penebaran 2 dan 4 ekor $/ \mathrm{m}^{2}$ berbeda tidak nyata, tetapi keduanya berbeda nyata dengan padat penebaran $8 \mathrm{ekor} / \mathrm{m}^{2}$ terhadap produksi udang windu, sedangkan ketiga padat penebaran saling berbeda nyata terhadap rasio konversi pakan (Tabel 3).

Pada padat penebaran yang sama, kelangsungan hidup dan berat individu merupakan faktor yang menentukan produksi. Walaupun tidak ada perbedaan nyata dari berat individu dan kelangsungan hidup udang windu pada ketiga padat penebaran, namun menghasilkan produksi yang berbeda nyata sebagai akibat adanya perbedaan padat penebaran yang juga merupakan faktor penentu produksi. 
Tabel 3. Karakteristik produksi udang windu pada padat penebaran berbeda di tambak tanah gambut $500 \mathrm{~m}^{2}$ selama 105 hari

Table 3. Production characteristics of tiger prawn raised for 105 days at different stocking densities in $500 \mathrm{~m}^{2}$ peat soil ponds

\begin{tabular}{|c|c|c|c|}
\hline \multirow[t]{2}{*}{$\begin{array}{l}\text { Variabel } \\
\text { Variables }\end{array}$} & \multicolumn{3}{|c|}{$\begin{array}{l}\text { Padat penebaran (ind. } / \mathrm{m}^{2} \text { ) } \\
\text { Stocking density }\left(\text { ind. } / \mathrm{m}^{2} \text { ) }\right.\end{array}$} \\
\hline & 2 & 4 & 8 \\
\hline $\begin{array}{l}\text { Awal: } \\
\text { berat individu }(\mathrm{g}) \\
\text { total berat }(\mathrm{kg}) \\
\text { jumlah individu }\end{array}$ & $\begin{array}{r}0,02 \\
0,02 \\
1.000\end{array}$ & $\begin{array}{r}0,02 \\
0,04 \\
2.000\end{array}$ & $\begin{array}{r}0,02 \\
0,08 \\
4.000\end{array}$ \\
\hline $\begin{array}{l}\text { Akhir: } \\
\text { berat individu (g) } \\
\text { total berat (kg) } \\
\text { jumlah individu }\end{array}$ & $\begin{array}{c}26,60^{a} \\
17,37^{b} \\
653\end{array}$ & $\begin{array}{c}27,73^{a} \\
25,15^{b} \\
907\end{array}$ & $\begin{array}{c}22,52{ }^{a} \\
52,78^{a} \\
653\end{array}$ \\
\hline Kelulusan hidup $\quad(\%)$ & $65,30^{a}$ & $45,35^{a}$ & $58,60^{a}$ \\
\hline Rasio konversi pakan & $1,60^{c}$ & $2,23 \mathrm{~b}$ & $2,52^{a}$ \\
\hline
\end{tabular}

The values in a row followed by similar superscript are not significantly different $(P>0.05)$

Hasil penelitian ini menunjukkan bahwa produksi tertinggi $(52,78 \mathrm{~kg} / 500$ $\mathrm{m}^{2}$ ) diperoleh pada padat penebaran yang tinggi pula $\left(8 \mathrm{ekor} / \mathrm{m}^{2}\right)$. Padat penebaran optimal belum dapat ditentukan, karena produksi masih menunjukkan peningkatan, meskipun berat individu sudah menurun pada padat penebaran yang lebih tinggi. Dengan demikian padat penebaran udang windu masih dapat ditingkatkan lebih dari $8 \mathrm{ekor} / \mathrm{m}^{2}$ sampai peningkatan produksi mengalami penurunan. Keadaan di mana padat penebaran mulai menyebabkan penurunan produksi menandakan bahwa daya dukung lahan sudah tercapai (Charpy, 1957 dalam Huet, 1978; Zonneveld et al., 1991) dan dapat digunakan untuk acuan penentuan padat penebaran optimal (Cholik et al., 1990).

Rasio konversi pakan meningkat dengan meningkatnya padat penebaran sehingga rasio konversi pakan tertinggi $(2,52)$ diperoleh pada padat penebaran tertinggi $\left(8 \mathrm{ekor} / \mathrm{m}^{2}\right)$. Hasil yang diperoleh lebih tinggi dibandingkan dengan temuan Mangampa dan Mustafa (1992) yaitu 1,67 pada padat penebaran 10 ekor $/ \mathrm{m}^{2}$. Apud et al. (1980) mendapatkan rasio konversi pakan sebesar 1,52; 1,71 ; dan 2,08 pada padat penebaran udang windu 2,5 ; 5 ; dan 10 ekor $/ \mathrm{m}^{2}$ selama 105 hari pemeliharaan di tambak. Selanjutnya Bose et al. (1991) 
mengatakan, padat penebaran merupakan satu di antara faktor yang mempengaruhi rasio konversi pakan.

Tingginya rasio konversi pakan yang ditemukan dalam penelitian ini dapat disebabkan oleh banyaknya pakan yang tidak termanfaatkan oleh udang windu sebagai akibat kualitas tanah dasar tambak yang kurang baik seperti terdapatnya koloid bahan organik, pembusukan bahan organik, kondisi aerob, dan adanya gas beracun seperti $\mathrm{H}_{2} \mathrm{~S}$. Kondisi dasar tambak demikian ini dapat menyebabkan pakan tidak terlihat oleh udang windu dan atau menurunkan kualitas pakan terutama aromanya.

\section{KESIMPULAN DAN SARAN}

1. Tambak tanah gambut yang digunakan dalam penelitian masih tergolong agak masam, masih berada pada tahap reaksi reduksi, kandungan bahan organik, Fe, dan rasio $\mathrm{C}-\mathrm{N}$ sangat tinggi.

2. Padat penebaran udang windu $2-8 \mathrm{ekor} / \mathrm{m}^{2}$ belum memberikan pengaruh yang nyata terhadap kualitas air tambak tanah gambut yang secara umum masih dapat mendukung kehidupan dan pertumbuhan udang windu.

3. Padat penebaran $2-8 \mathrm{ekor} / \mathrm{m}^{2}$ tidak memberikan pengaruh nyata terhadap berat individu dan kelangsungan hidup, tetapi berpengaruh nyata terhadap produksi udang windu. Berat individu tertinggi $(27,73 \mathrm{~g})$ diperoleh pada padat penebaran 4 ekor $/ \mathrm{m}^{2}$, kelangsungan hidup tertinggi $(65,30 \%)$ diperoleh pada padat penebaran terendah $\left(2 \mathrm{ekor} / \mathrm{m}^{2}\right)$, sedangkan produksi tertinggi $\left(52,78 \mathrm{~kg} / 500 \mathrm{~m}^{2}\right)$ diperoleh pada padat penebaran tertinggi $(8$ ekor $\left./ \mathrm{m}^{2}\right)$. Sedangkan rasio konversi pakan terendah yaitu 1,60 diperoleh pada padat penebaran terendah $\left(2 \mathrm{ekor} / \mathrm{m}^{2}\right)$.

4. Penelitian budidaya udang windu pada padat penebaran di atas $8 \mathrm{ekor} / \mathrm{m}^{2}$ di tambak tanah gambut disarankan untuk memperoleh padat penebaran optimal.

\section{UCAPAN TERIMA KASIH}

Diucapkan banyak terima kasih kepada Sdr. Ashar, mahasiswa Fakultas Perikanan, Universitas Muslim Indonesia Ujung Pandang yang banyak membantu dalam pelaksanaan penelitian di lapang dan Sdri. Reny Yulianingsih, teknisi litkayasa Balitkanta Maros atas bantuan analisis kualitas air dan tanah dari penelitian ini.

\section{DAFTAR PUSTAKA}

Ahmad, T., 1991. Pengelolaan peubah mutu air yang penting dalam tambak udang intensif. Balai Penelitian Perikanan Budidaya Pantai, Maros. 37 hal. 
Akiyama, D.M. and N.L.M. Chwang, 1989. Shrimp feed requirements and feed management. p. 75-82. In D.M. Akiyama (ed.), Proceeding of the Southeast Asia Shrimp Farm Management Workshop. American Soybean Association, Singapore.

Apud, F.D., 1988. Prawn grow-out practices in the Philippines. p.89-118. In Biology and Culture of Penaeus monodon. SEAFDEC, Tigbauan, Iloilo, Philippines.

Apud, F.D., K. Gonzales, and N. Deatras, 1980. Survival, growth production of Penaeus monodon at different stocking densities in earthen ponds with flow-through system and supplementary feeding. Fourt Quart. Res. Report IV(4):15-18.

ASEAN (Association of Southeast Asian Nations), 1978. Manual on pond culture of penaeid shrimp. ASEAN National Coordinating Agency of The Philippines, Manila. 122 pp.

Blanco, G.J., 1972. Status dan problem of coastal aquaculture in The Phillipines. p. 60-67. In T.V.R. Pillay (ed.), Coastal Aquaculture in The Indo-Pacific region. Fishing News (Books) Ltd., London.

Bose, A.N., S.N.Ghosh, C.T.Yang, and A.Mitra, 1991. Coastal aquaculture engineering. Chapman and Hill, Inc., New York, 365 pp.

Chen, T.P., 1972. Fertilization and feeding in coastal fish farm in The Taiwan. p. 410-416. In T.V.R. Pillay (ed.), Coastal Aquaculture in The Indo-Pacific region. Fishing News (Books) Ltd., London.

Cholik, F., Rachmansyah, dan S.Tonnek, 1990. Pengaruh padat penebaran terhadap produksi nila merah, Oreochromis niloticus dalam keramba jaring apung di laut. J.Penel.Budidaya Pantai 6(2):87-96.

Huet, M., 1978. Textbook of fish culture: Breeding and cultivation of fish. Phoenix Press, Inc., Queson City, Philippines. 436 p.

Liao, I.C., 1977. A culture study on grass prawn, Penaeus monodon in Taiwan: The pattern, the problems and the prospects. Collect. Rep. Tungkang Mar. Lab. 3:141-161.

Maguire, B.B. and M.I. Leedow, 1983. A study of the optimal stocking density and feed rate for school prawns, Metapenaeus macleayi (Haswell) in some Australian brackishwater farming ponds. Aquaculture 30:285-297.

Mangampa, M. dan A.Mustafa, 1992. Budidaya udang windu, Penaeus monodon pada padat penebaran yang berbeda dengan menggunakan benih yang dibantut. J. Penelitian Budidaya Pantai 8(4):37-48.

Mustafa, A., A.Hanafi, dan B.Pantjara, 1992. Pengaruh frekuensi pengolahan tanah terhadap kualitas tanah dan air serta pertumbuhan dan kelangsungan 
hidup udang windu di tambak tanah gambut. Laporan Penelitian Balai Penelitian Perikanan Budidaya Pantai, Maros.

Mustafa, A., A.Hanafi, dan B.Pantjara, 1993. Pengaruh berbagai dosis kapur pertanian terhadap kualitas tanah gambut. J. Penelitian Budidaya Pantai 9(4):109-120.

Mustafa, A., A. Hanafi, dan B. Pantjara. 1994. Pengaruh reklamasi terhadap kualitas tanah dan air tambah tanah gambut. J. Penelitian Budidaya Pantai 10(2):

Papoutsoglou, S.E., E. Papaparaskeva-Papoutsoglou, and M.N. Alexis, 1987. Effect of density on growth rate and production of rainbow trout (Salmo gairdneri Rich.) over a full rearing period. Aquaculture 66:9-17.

Petersen, R.G., 1985. Design and analysis of experiment. Marcel Dekker, Inc., New York-Basel. 429 pp.

Poernomo, A., 1988. Pembuatan tambak udang di Indonesia. S.Sunarno dan S.Dahlan (eds.). Seri Pengembangan No. 7. Balai Penelitian Perikanan Budidaya Pantai, Maros. 30 hal.

Ricker, W.E., 1975. Computation and interpretation of biological statistics of fish populations. Bull. Fish. Res. Board Can. 191:382 p.

Suhardjo, H., 1994. Tanah gambut. Pusat Penelitian Tanah dan Agroklimat, Bogor. 2 hal.

Trino, A.T., V.D.Penaflorida, and E.C.Bolivar, 1992. Growth and survival of Penaeus monodon juveniles fed a diet lacking vitamin supplements in a modified extensive culture system. Aquaculture 101:25-32.

Widjaja-Adhi, I P.G., 1994. Lahan rawa di Kawasan Timur Indonesia: Potensi, pengelolaan dan teknologi pengembangannya. hal. 324-341. Dalam H.Suhardjo, J.S.Adiningsih, A.Mulyani, Irawan, R.Syamsulbahri, dan S.E.Aprillani (eds.), Prosiding Temu Konsultasi Sumberdaya Lahan untuk Pengembangan Kawasan Timur Indonesia, Palu, 17-20 Januari 1994. Pusat Penelitian Tanah dan Agroklimat, Bogor.

Wallace, J.C., A.G.Kolbeinshavn, and T.G.Reinsnes, 1988. The effects of stocking density on early growth in Arctic Charr, Salvelinus alpinus (L.). Aquaculture 73:101-110.

Wyban, J.A., C.S.Lee, V.T.Sato, J.N.Sweeney, and W.K.Richards Jr., 1987. Effect of stocking density on shrimp growth rates in manure-fertilized ponds. Aquaculture 61:23-32.

Zonneveld, N., E.A.Huisman, dan J.H.Boon, 1991. Prinsip-prinsip budidaya ikan. PT Gramedia Pustaka Utama, Jakarta. 318 hal.

Zonneveld, N. and R.Fadholi, 1991. Feed intake and growth of red tilapia at different densities in ponds Indonesia. Aquaculture 99:83-94. 